\title{
Import Liberalization and Import Tariff Yield in Ghana: Estimating Tariff Buoyancy and Elasticity
}

\author{
William Gabriel Brafu-Insaidoo", Camara Kwasi Obeng \\ Department of Economics, University of Cape Coast, Cape Coast, Ghana
}

\begin{abstract}
The basic objective of the study is to evaluate the import tariff yield in Ghana, and investigate the impact of import liberalization and customs reforms on the yield. Theory suggests that the relationship between import liberalization and tariff revenue is ambiguous. Empirical studies also indicate that there is no clear link between import liberalization and tariff revenue. To achieve the stated objective, the import tariff buoyancy and elasticity for the pre-reform and reform periods as well as the impact of the liberalization on the yield were estimated. The study confirms the hypothesis that tariff reforms improve tariff revenue yield.
\end{abstract}

Keywords import liberalization, tariff buoyancy and the elasticity, tariff revenue

\section{Introduction}

Trade liberalization has formed a very important component of economic reform programmes in Ghana since 1983. In terms of sequencing, Ghana did not go through the normal intermediary stage of translating quantitative restrictions into equivalent tariffs before gradually reducing the tariffs. Most quantitative restrictions, including import licensing, were eliminated at the same time as the country went ahead to reduce the level and range of tariffs (WTO, 2001).

The main reason for import trade liberalization under economic reforms was to reduce the wedge between the official and the parallel exchange rates. Also important was the need to provide foreign exchange to ease import suppression with the aim of increasing output, particularly in the export sector. In this regard, the long-term goal was to replace quantitative restrictions with price instruments. More recently, the impact of the liberalization on trade tax revenue has been a subject of debate. There are concerns about existing ambiguity in both theory and empirical evidence on the relationship between trade liberalization and trade tax revenue in the global context. In theory, liberalization in the form of lower tariff rates and the simplification of rates causes direct trade tax revenue loss, on the one hand, but on the other can also amount to an increase in volume of imports, and hence the tax base and revenue. The net effect depends on a host of factors, including the initial trade regime and the extent of increase in demand for imports. Empirical studies confirm this ambiguous relationship suggested in theory (see

* Corresponding author:

winsaidoo@yahoo.com (William Gabriel Brafu-Insaidoo)

Published online at http://journal.sapub.org/economic

Copyright (C) 2012 Scientific \& Academic Publishing. All Rights Reserved
Tanzi, 1989; Ebrill et al., 1999; Glenday, 2000; Khattry et al., 2002; Agbeyegbe et al., 2004; UNECA, 2004; Suliman, 2005; Greenaway and Milner, 1993).

Oduro (2000) asserts that trade liberalization was fiscally incompatible in Ghana during the 1990s even though Jebuni et al. (1994) find it fiscally compatible for the second half of the 1980s. Such studies rely only on descriptive analyses of changes in tax revenues. They do not apply testable models in investigating the exact impact of trade liberalization on trade tax revenues in Ghana. In order to validate Oduro's assertion, this study used regression analysis applied to testable models to examine the relationship between import liberalization and import tariff yield in Ghana.

The basic objective of the study is to evaluate the import tariff yield in Ghana, and answer the question of whether there is any significant difference in import tariff yield between the pre-reform (1965 to 1982) and reform (1983 to 2007) period. The study is meant to determine the efficiency of the trade tax administration system and to find out whether revenue leakage remains a major problem for import tax after trade liberalization.

To meet the stated objective, this study estimated the import tariff buoyancy and elasticity for the pre-reform (1965 to 1982) and reform (1983 to 2007) period in Ghana. The study also estimated the link between import liberalization and customs reforms on one hand and tariff revenue performance on the other hand in Ghana.

The only identified study that evaluated the revenue productivity of Ghana's tax system is that of Kusi (1998) which identified a sharp improvement in the revenue productivity during the reform period. Exchange rate reforms including successive currency devaluations, import liberalization and tax reforms including further improvement in the tax administration are mentioned in the study as some of the major 
factors accounting for the improved tax revenue performance. Kusi's approach, however, only covers the period from 1970 to 1993 , which makes a sample period of 23 years. In contributing to knowledge on revenue productivity of Ghana's import tax system, this study adds value by estimating the decomposed tariff buoyancies and extends the study period to 42 years, from 1965 to 2007 .

\section{Methodology}

\subsection{Method of Analysis}

Two measures are usually used for determining tax yield. These are the buoyancy and the elasticity of a given tax system. The buoyancy measures growth in duty revenue as a result of growth in income, reflecting the combined effects of tax base expansion and discretionary changes in tax rates, base definition, and changes in collection and enforcements of the law. Elasticity measures, on the other hand, control for discretionary tax measures, implying that changes in duty revenues are attributed to automatic or natural growth of the economy (Osoro, 1993).

Generally, the buoyancy of a tax is obtained by assuming the following functional form:

$$
\mathrm{TR}=\alpha \mathrm{Y}^{\beta} \varepsilon
$$

This can be rewritten in double $\log$ as follows:

$$
\log T R_{\mathrm{t}}=\log \alpha+\beta \log Y_{\mathrm{t}}+\varepsilon_{\mathrm{t}}
$$

where $T R$ and $Y$ are real import tariff revenue and income or GDP in aggregate level, respectively, and $\alpha$ and $\varepsilon$ represent a constant and error term, respectively. The parameter $\beta$ then becomes the direct measure of buoyancy. It follows from Equation 1 that $(\partial \mathrm{TR} / \partial \mathrm{Y})(\mathrm{Y} / \mathrm{TR})=\beta$.

The buoyancy of a tax system, which generally refers to the responsiveness of tax revenue to a change in income, is defined as:

$$
\begin{gathered}
\mathrm{E}_{\mathrm{t}, \mathrm{y}}=(\partial \mathrm{TR} / \partial \mathrm{Y}) *(\mathrm{Y} / \mathrm{TR})= \\
{[(\partial \mathrm{TR} / \partial \mathrm{B}) *(\mathrm{~B} / \mathrm{TR})][(\partial \mathrm{B} / \partial \mathrm{Y}) *(\mathrm{Y} / \mathrm{B})]}
\end{gathered}
$$

where TR is tax revenue, $\mathrm{Y}$ is income (GDP) and $\partial$ denotes partial derivatives. The right-hand side of Equation 3 represents a decomposed version of the tariff buoyancy, interpreted as elasticity of tariff revenue with respect to tax base (imports in this case) and the elasticity of the base with respect to income (GDP). Overall, tax base-to-income elasticities can be determined by how the economic structure changes with economic growth. The tax-to-base elasticities, on the other hand, show the revenue growth that is within the control of customs administration or that can be attributed to efficiency in customs administration.

To find out the responsiveness of tariff revenue to change in the tax base, we assume the following functional form:

$$
\mathrm{TR}=\mathrm{aB}^{\mathrm{b}} \mathrm{v}
$$

This can be rewritten in double log form as follows:

$$
\log T R_{\mathrm{t}}=\log a+\mathrm{bLog} B_{\mathrm{t}}+v_{\mathrm{t}}
$$

where $T R$ and $B$ are import tariff revenue and the tax base (imports $M$, in this case) respectively, and $a$ and $v$ represent a constant and error term, respectively. The parameter $b$ then becomes the direct measure of the responsiveness of import tax revenue to change in the tax base. It follows from Equation 4 that $(\partial T R / \partial B)(B / T R)=b$.

In determining elasticities, two main techniques are usually used for cleansing the revenue series of discretionary effects. One is that of proportional adjustment, which involves use of historical time series tax data adjusted for discretionary tax measures, as in Mansfield (1972), Osoro (1993), and Muriithi and Moyi (2003). The other is the use of unadjusted historical time series tax data with time trends or dummy variables incorporated as proxies for discretionary tax measures, as in Singer (1968) and Artus (1974).

Lack of sufficient data made us opt for the dummy method, usually referred to as the Singer approach. Thus, we introduce dummy variables to control for discretionary tax measures and a lagged base variable into Equation 5 as follows:

$$
\log T R_{\mathrm{t}}=\log a+\mathrm{b}_{1} \log B_{\mathrm{t}}+\mathrm{b}_{2} \log B_{\mathrm{t}-1}+\sum \mathrm{b}_{3 \mathrm{i}} D_{\mathrm{i}}+v_{\mathrm{t}}
$$

where the dummy variable $D$ takes on the value of one for discretionary tax measures and zero otherwise. The summation accounts for the multiple discretionary changes over the sample period. More specifically, three dummies are introduced. A liberalization dummy, $D_{1983}$, is introduced as a dummy for tariff reforms undertaken to accommodate import liberalization initiated in 1983 measures. A second dummy, $D_{\text {slope, }}$ which is an interactive term, is a slope dummy introduced to capture any shift in the slope of the tariff revenue function as a result of the liberalization. $D_{\text {slope }}$ is defined as $T R * D_{1983}$, where $T R$ denotes tariff revenue. The third dummy, $D_{t a r}$, is introduced to capture the impact of customs administration reforms in Ghana. Tax reforms in Ghana started with the establishment of the National Revenue Secretariat with an oversight responsibility of supervising the operations of revenue collection agencies, as well as the granting of autonomy to the agencies including customs administration in 1985.

\subsection{Data Sources and Definition of Variables}

Annual data for the study was collected from the Ghana Statistical Services, Customs, Excise and Preventive Services, and the Ministry of Finance and Economic Planning.

For this paper, the following variable definitions applied. Real import tax or duty revenue was calculated by deflating nominal import duty revenues with the consumer price index. The values of real imports were obtained by deflating nominal imports with import price indices. Real GDP is nominal GDP deflated by GDP deflator.

\section{Import Tax Yield - Buoyancy and Elasticity}

Estimates of the import tariff buoyancy and elasticity have been derived using the Cochrane-Orcutt iterative procedure, which corrects for the problem of multicollinearity and autocorrelation. Report of the estimates on tariff buoyancy is presented in Table 1. The estimates indicate that import tax 
has become more buoyant over the period of import liberalization compared to the pre-reform period (before 1983).

On the contrary, Table 2 indicates that the import tariff has become less elastic over the period of import liberalization compared with the pre-reform period. The comparatively low elasticity for the reform period might be attributed to the continued prevalence of duty evasion, duty exemptions, corruption in customs administration and smuggling activities.

Table 1. Estimates of import tariff buoyancy in Ghana

\begin{tabular}{|c|c|c|}
\hline Period & Coefficient & DW \\
\hline $1965-2003$ & 1.282 & 1.705 \\
\hline $1965-1982$ & 0.299 & 1.779 \\
\hline $1983-2007^{*}$ & 2.562 & 1.751 \\
\hline Difference in coefficients & 2.263 & \\
\hline
\end{tabular}

Source: Computed by the authors using Stata 9.0

In particular, there has been widespread use of discretionary exemptions, often administered under poorly specified authority. It is estimated that about $14 \%$ of total imports in 1998 alone, passed through bonded warehouses, including many duty-free goods. Bonded goods are estimated to be the single largest category of exempt imports, accounting for 35\% of total exempt imports (Brafu-Insaidoo and Obeng, 2008). This common use of bonded warehouses tends to contribute to duty evasion. Duty evasion also arises from under- invoicing of imports and outright smuggling, often with the connivance of corrupt customs officials.

Table 2. Estimates of overall elasticity of tariff revenue in Ghana

\begin{tabular}{|c|c|c|}
\hline Period & Coefficient & DW \\
\hline $1965-2003 *$ & 0.290 & 1.740 \\
\hline $1965-1982 *$ & 0.821 & 1.622 \\
\hline $1983-2007$ & 0.015 & 1.983 \\
\hline Difference in coefficients & -0.806 & \\
\hline
\end{tabular}

Source: Computed by the authors using Stata 9.0

Table 3. The decomposed tariff buoyancies over the reform and prereform period in Ghana

\begin{tabular}{|c|c|c|}
\hline Period & Coefficient & DW \\
\hline \multicolumn{3}{|c|}{ Base-to-income elasticity } \\
\hline $1965-2003^{*}$ & 3.183 & 1.282 \\
\hline $1965-1982$ & 2.144 & 1.017 \\
\hline $1983-2007^{*}$ & 6.074 & 1.056 \\
\hline \multicolumn{2}{|c|}{ Tax-to-base elasticity } \\
\hline Difference in coefficients & 0.480 & 1.910 \\
\hline $1965-2003^{*}$ & 0.468 & 1.849 \\
\hline $1965-1982^{*}$ & 0.313 & 1.906 \\
\hline Difference in coefficients & -0.155 & \\
\hline
\end{tabular}

Source: Computed by the authors using Stata 9.0

Estimates of the decomposed tariff buoyancies (Table 3) indicate high growth of taxable imports over the liberalization period compared with the pre-liberalization (pre-1983) period. This supports earlier analysis showing that imports have grown substantially over the period of import liberalization under the economic reforms initiated in 1983. However, the liberalization period has also witnessed a com- paratively slowed growth in tariff revenue. This observation implies that the administration of collection of duties has remained weak, despite earlier efforts to strengthen it. The estimates of the tax-to-base elasticity indicate that elasticity fell from 0.468 during the pre-reforms period (pre-1983 period) to 0.313 during the liberalization period (since 1983). This suggests the need to further strengthen and improve duty collection administration in Ghana.

Estimates of the elasticity of tariff revenue presented in the Appendix, tables A4, A8 and A12, indicate that the coefficient of the lagged base variable has a negative sign for the pre-liberalization period. This implies that there had been administrative inefficiencies in the customs duty collection for the pre-liberalization period. The lags in tax collection can be very expensive to the economy particularly for the years in which the country experiences high inflation. The situation has improved over the liberalization period.

A comparison of duty buoyancy and elasticity (Table 4) indicates that duty buoyancy outweighed duty elasticity when considering the entire study period, a suggestion that discretionary tax measures (DTMs) have improved tariff revenue mobilization over the entire period. A comparison of regimes, however, indicates that the contribution of DTMs in improving tariff revenue mobilization has been positive during the period of import liberalization. Measures such as comprehensive reforms to customs duties (which includes reduction of the level and range of rates) and customs collection administration have improved efficiency in the import tax system during the liberalization period.

Table 4. Comparison of import tax buoyancy and elasticity in Ghana

\begin{tabular}{|c|c|c|c|}
\hline Period & Buoyancy & Elasticity & Difference \\
\hline $1965-2003$ & 1.282 & 0.290 & 0.992 \\
\hline $1965-1982$ & 0.299 & 0.821 & -0.522 \\
\hline $1983-2007$ & 2.562 & 0.015 & 2.547 \\
\hline
\end{tabular}

Source: Computed by the authors using Stata 9.0

Overall, evidence obtained indicates that import tax is buoyant in Ghana, in particular during the period of import liberalization (from 1983 to 2007).

A cursory look at the Table A4 under the appendix also indicates that although import liberalization has significantly amounted to some revenue loss, the significance of the interactive slope dummy in explaining tariff revenue suggests that the slope of the tariff revenue function has shifted upward as a result of import liberalization. This could mean that the share of commodities subject to tariff in total imports has increased.

\section{Conclusions and Policy Implications}

Ghana has been hailed by the international community as one of the countries that have pursued deep economic reforms since 1983. As part of the programme, efforts have been made to reform the external trade sector with import liberalization as an important component. Among the instruments used were reductions in the level of tariffs, sim- 
plification of rates into more uniform rates, the removal or relaxation of quantitative restrictions, and the equilibrating role of a liberal exchange rate regime.

However, experiences with tax revenues from international trade, particularly during the 1980s and 1990s, raised concerns about whether import trade liberalization conflicts with the revenue generation objectives of economic reform in Ghana. This has been important because fiscal discipline in the earlier part of adjustment was relaxed and government was no longer prudent with its spending. We have attempted in this study to address one of the prevailing issues in the trade liberalization debate.

\subsection{Conclusions}

The basic objective of the study was to evaluate the import tariff yield in Ghana, and answer the question of whether there is any significant difference in import tariff yield between the pre-reform (1965 to 1982) and reform (1983 to 2007) period. To do this we estimated the import tax buoyancy and elasticity in Ghana.

The findings from the analysis are as follows:

- Import tax has become more buoyant over the period of liberalization compared to the pre-reform period (pre-1983)

- Import tariff has become less elastic over the period of import liberalization compared with the pre-reform period. This might be attributed to the continued prevalence of duty evasion, duty exemptions, corruption in customs administration and smuggling activities during the period of reforms (post-1983 period).

- The degree of responsiveness of import tax to change in its taxable base declined during the liberalization period compared with the pre-liberalization period.

- Discretionary tax measures, such as reforms made to the tariff structure in conformity to import liberalization, the temporary introduction of special import tax on selected items, and reforms to customs administration such as the granting of operational autonomy, improved tariff revenue mobilization over the liberalization period.

- A cursory look at Table A4 under appendix, also indicates that although import liberalization has resulted in some revenue loss, the significance of the interactive slope dummy in explaining tariff revenue suggests that the tariff revenue function has shifted upward as a result of the liberalization. This could mean that the share of commodities subject to tariff in total imports increased.

In sum, this study confirms the findings from the earlier work by Kusi (1998) that customs reforms, including tariff liberalization and the overhauling of the tax administration has improved tariff revenue yield and efficiency in Ghana's import tax system during the liberalization period.

\subsection{Policy Implications}

Nevertheless, the study also indicates that there is a continued existence of substantial amount of leakage and inefficiencies in the customs collection system. Thus, customs administration requires further strengthening to generate more duty revenue from imports. Leakages in the customs collection system could in part be attributed to the exploitation of widespread duty exemptions, outright smuggling and import under-invoicing in the country.

Public policy should focus on the identification of the major sources of duty revenue leakage. The pervasive use of exemptions creates a gap in the tax base, especially through abuses of the exemptions offered. A further review of the rationale for the duty exemption programme and reduction in range of items exempt from duty payments in Ghana will be required. Improving revenue administration and closing other sources of leakages including import under-invoicing on a committed and continuous basis, will help to broaden the tax base and to recover revenue (IMF, 2005). An effective measure, in this regard, is to strengthen the tax collection system, including institutional reforms (automation and strengthening of monitoring and supervision units). Collaboration with source country Customs officials will help to trace or confirm the actual costs of goods that are often under-invoiced, as is common practice in Ghana. In addition, the promotion of rapid economic growth during liberalization will further shore up tariff revenue for a given level of tariffs (Ebrill, Stotsky and Gropp, 1999).

\section{Appendix}

Table A1. Import Tax Buoyancy (1965 to 2007)

\begin{tabular}{|c|c|c|c|c|}
\hline Log tr & Coefficient & Standard error & $\mathrm{t}$ & $\mathrm{P}>\{\mathrm{t}\}$ \\
\hline Constant & (dropped) & & & \\
\hline Log Y & 1.282 & 0.809 & 1.58 & 0.121 \\
\hline
\end{tabular}

$D$-W (original) $0.192 \mathrm{D}$-W (transformed) 1.705

Note: The estimates are obtained after applying the Cochrane-Orcutt iterative process to correct for the problem of autocorrelation and multicollinearity Source: Computed by authors, using Stata 9.0

Table A2. Base-to-income elasticity (1965 to 2007)

\begin{tabular}{|c|c|c|c|c|}
\hline Log m & Coefficient & Standard error & $\mathrm{t}$ & $\mathrm{P}>\{\mathrm{t}\}$ \\
\hline Constant & (dropped) & & & \\
\hline Log Y & 3.183 & 0.891 & 3.57 & 0.001 \\
\hline
\end{tabular}

$D$-W (original) 0.225 D-W (transformed) 1.282 Source: Computed by authors using Stata 9.0

Table A3. Tax-to-base elasticity (1965 to 2007)

\begin{tabular}{|c|c|c|c|c|}
\hline Log tr & Coefficient & Standard error & $\mathrm{t}$ & $\mathrm{P}>\{\mathrm{t}\}$ \\
\hline Constant & 0.946 & 0.355 & 2.67 & 0.011 \\
\hline Log $\mathrm{m}$ & 0.480 & 0.936 & 5.13 & 0.000 \\
\hline
\end{tabular}

$D$-W (original) 0.447 D-W (transformed) 1.910

Source: Computed by authors using Stata 9.0

Table A4. Estimates of overall elasticity of tariff revenue (1965 to 2007)

\begin{tabular}{|c|c|c|c|c|}
\hline Log tr & Coefficient & Standard error & $\mathrm{t}$ & $\mathrm{P}>\{\mathrm{t}\}$ \\
\hline Constant & (dropped) & & & \\
\hline Log $\mathrm{m}$ & 0.290 & 0.098 & 2.96 & 0.005 \\
\hline $\log { }_{-} 1$ & -0.260 & 0.589 & -0.44 & 0.661 \\
\hline Dslope & 0.887 & 0.170 & 5.22 & 0.000 \\
\hline $\mathrm{D}_{\operatorname{tax}}$ & -0.040 & 0.095 & -0.42 & 0.678 \\
\hline $\mathrm{D}_{1983}$ & -1.519 & 0.339 & -4.49 & 0.000 \\
\hline
\end{tabular}

$D-W$ (original) 1.636 D-W (transformed) 1.740

Source: Computed by authors using Stata 9.0 
Table A5. Import Tax Buoyancy (1965 to 1982)

\begin{tabular}{|c|c|c|c|c|}
\hline Log tr & Coefficient & Standard error & $\mathrm{t}$ & $\mathrm{P}>\{\mathrm{t}\}$ \\
\hline Constant & (dropped) & & & \\
\hline Log Y & 0.299 & 1.329 & 0.23 & 0.825 \\
\hline
\end{tabular}

$D$-W (original) $0.175 D$-W (transformed) 1.779

Source: Computed by authors using Stata 9.0

Table A6. Base-to-income elasticity (1965 to 1982)

\begin{tabular}{|c|c|c|c|c|}
\hline Log tr & Coefficient & Standard error & $\mathrm{t}$ & $\mathrm{P}>\{\mathrm{t}\}$ \\
\hline Constant & (dropped) & & & \\
\hline Log Y & 2.144 & 1.401 & 1.53 & 0.145 \\
\hline
\end{tabular}

$D$-W (original) $0.168 D$-W (transformed) 1.017

Source: Computed by authors using Stata 9.0

Table A7. Tax-to-base (1965 to 1982)

\begin{tabular}{|c|c|c|c|c|}
\hline Log tr & Coefficient & Standard error & $\mathrm{t}$ & $\mathrm{P}>\{\mathrm{t}\}$ \\
\hline Constant & (dropped) & & & \\
\hline Log $\mathrm{m}$ & 0.468 & 0.188 & 2.49 & 0.024 \\
\hline
\end{tabular}

$D$-W (original) $0.856 D$-W (transformed) 1.849

Source: Computed by authors using Stata 9.0

Table A8. Estimates of overall elasticity of tariff revenue (1965 to 1982)

\begin{tabular}{|c|c|c|c|c|}
\hline Log tr & Coefficient & Standard error & $\mathrm{t}$ & $\mathrm{P}>\{\mathrm{t}\}$ \\
\hline Constant & (dropped) & & & \\
\hline Log $\mathrm{m}$ & 0.821 & 0.224 & 3.67 & 0.003 \\
\hline Log $\mathrm{m} \_1$ & -0.221 & 0.266 & -0.83 & 0.421 \\
\hline logy_1 & -0.675 & 1.138 & -0.59 & 0.564 \\
\hline Dslope & 0.123 & 0.072 & 1.72 & 0.111 \\
\hline
\end{tabular}

$D$-W (original) $1.278 D$-W (transformed) 1.622

Source: Computed by authors using Stata 9.0

Table A9. Import Tax Buoyancy (1983 to 2007)

\begin{tabular}{|c|c|c|c|c|}
\hline Log tr & Coefficient & Standard error & $\mathrm{t}$ & $\mathrm{P}>\{\mathrm{t}\}$ \\
\hline Constant & (dropped) & & & \\
\hline Log Y & 2.562 & 0.958 & 2.67 & 0.014 \\
\hline
\end{tabular}

$D$-W (original) $0.545 D$-W (transformed) 1.751

Source: Computed by authors using Stata 9.0

Table A10. Base-to-income (1983 to 2007)

\begin{tabular}{|c|c|c|c|c|}
\hline Log $\mathrm{m}$ & Coefficient & Standard error & $\mathrm{t}$ & $\mathrm{P}>\{\mathrm{t}\}$ \\
\hline Constant & (dropped) & & & \\
\hline$\Delta$ Log Y & 6.074 & 2.157 & 2.82 & 0.010 \\
\hline
\end{tabular}

$D$-W (original) $0.276 D$ - $W$ (transformed) 1.056

Source: Computed by authors using Stata 9.0

Table A11. Tax-to-base elasticity (1983 to 2007)

\begin{tabular}{|c|c|c|c|c|}
\hline Log tr & Coefficient & Standard error & $\mathrm{t}$ & $\mathrm{P}>\{\mathrm{t}\}$ \\
\hline Constant & (dropped) & & & \\
\hline Log $\mathrm{m}$ & 0.313 & 0.141 & 2.22 & 0.036 \\
\hline
\end{tabular}

$D$-W (original) $0.730 D-W$ (transformed) 1.906

Source: Computed by authors using Stata 9.0

Table A12. Estimates of overall elasticity (1983 to 2007)

\begin{tabular}{|c|c|c|c|c|}
\hline Log tr & Coefficient & Standard error & $\mathrm{t}$ & $\mathrm{P}>\{\mathrm{t}\}$ \\
\hline Constant & -1.644 & 2.280 & -0.72 & 0.480 \\
\hline Log $\mathrm{m}$ & 0.015 & 0.228 & 0.06 & 0.950 \\
\hline Log $\mathrm{m} \_1$ & 0.198 & 0.247 & 0.80 & 0.432 \\
\hline Log $\mathrm{Y} \_1$ & 0.908 & 0.780 & 1.16 & 0.259 \\
\hline $\mathrm{D}_{\operatorname{tax}}$ & 0.106 & 0.132 & 0.80 & 0.433 \\
\hline
\end{tabular}

$D$-W (original) $0.754 D$-W (transformed) 1.983

Source: Computed by authors using Stata 9.0

\section{REFERENCES}

[1] T. Agbeyegbe, J. G. Stotsky and M. W. Asegedech, "Trade liberalization, exchange rate changes, and tax revenue in Sub-Saharan Africa," IMF Working Paper WP/04/178, International Monetary Fund, Washington, D.C., 2004.

[2] K. K. Artus, "Tax Revenue Forecasting: A Methodological Study with Application to Turkey," Studies in Domestic Finance, No. 5, Washington, D.C.: The World Bank, 1974.

[3] W. G. Brafu-Insaidoo and C. K. Obeng, "Effect of Import Liberalization on Tariff Revenue in Ghana," AERC Research Paper, No. 180: African Economic Research Consortium, Nairobi, 2008.

[4] L. Ebrill, J. Stotsky and R. Gropp, "Revenue Implications of Trade Liberalization," Occasional Paper No. 99/80, 1999, International Monetary Fund, Washington, D.C., 1999.

[5] G. Glenday, "Trade Liberalization and Customs Revenues: Does Trade Liberalization Lead to Lower Customs Revenues? The Case of Kenya," Development Discussion Papers No. 764, Harvard Institute for International Development, Cambridge, Massachusetts, 2000.

[6] D. Greenaway and C. Milner, "The Fiscal Implications of Trade Reform: Theory and Evidence", Occasional Paper No. 9, UNDP and World Bank Trade Expansion Programme, Washington, D.C, 1993.

[7] C. D. Jebuni, A. D. Oduro and K. A. Tutu, "Trade, Payments Liberalization and Economic Performance in Ghana", AERC Research Paper No. 27, African Economic Research Consortium, Nairobi, 1994.

[8] B. Khattry and J. M. Rao, "Fiscal faux pas?: An analysis of the revenue implications of trade liberalization," World Development, 30, pp. 1431-44. 2002.

[9] N. K. Kusi, "Tax Reforms and Revenue Productivity in Ghana," AERC Research Paper No. 74: African Economic Research Consortium, Nairobi, 1998.

[10] C. Y. Mansfield, "Elasticity and buoyancy of a tax system: A method applied to Paraguay". IMF Staff Papers, 19(2): 425-46, 1972.

[11] M. K. Muriithi and E. D. Moyi, "Tax Reforms and Revenue Mobilization in Kenya", AERC Research Paper No. 131, African Economic Research Consortium, Nairobi, 2003.

[12] A. D. Oduro, "Performance of the external trade sector since 1970", In E. Aryeetey, J. Harrigan and M. Nissanke, eds., Economic Reforms in Ghana. New Jersey: Africa World Press, 2000.

[13] N. E. Osoro "Revenue Productivity Implication of Tax Reform in Tanzania," AERC Research Paper No. 20. African Economic Research Consortium, Nairobi, 1993.

[14] H. M. Singer, "The use of dummy variables in estimating the income elasticity of state income tax revenues" National Tax Journal, vol. 21: 200-204, 1968.

[15] International Monetary Fund, 2005, "Dealing with the revenue consequences of trade reform," A background paper for review prepared by the Fiscal Affairs Department, IMF.

[16] K. M. Suliman, 2005, "The impact of trade liberalization on revenue mobilization and stability in Sudan". Global Devel- 
opment Network. http://www.gdnet.org/pdf2/gdn_library/ global_research_projects/macro_low_income/Suliman.pdf. Accessed 2 May 2007

[17] V. Tanzi "The impact of macroeconomic policies on the level of taxation and the fiscal balance in developing countries". IMF Staff Papers, 36(3): 633-56, 1989.
[18] UNECA, Economic Report on Africa 2004. Addis Ababa: United Nations Economic Commission for Africa, 2004.

[19] WTO. 2001. Trade Policy Review Ghana. No. 81. Geneva: World Trade Organization. Switzerland.http://www.wto.org/ english/tratop_e/tpr_e/tp157_e.htm. Accessed 2 May 2007 